REVIEW

\title{
History of asbestos related disease
}

\author{
P W J Bartrip
}

Postgrad Med J 2004;80:72-76. doi: 10.1136/pmj.2003.012526

The first medical article on the hazards of asbestos dust appeared in the British Medical Journal in 1924. Following inquiries by Edward Merewether and Charles Price, the British government introduced regulations to control dangerous dust emissions in UK asbestos factories. Until the 1960s these appeared to have addressed the problem effectively. Only then, with the discoveries that mesothelioma was an asbestos related disease and that workers other than those employed in the dustiest parts of asbestos factories were at risk, were the nature and scale of the hazard reassessed. In Britain, America, and elsewhere new and increasingly strict regulations were enacted. companies, such as Johns-Manville, the American giant that dominated the industry for many years, ran to scores of pages. So asbestos had many "upsides". Unfortunately, it also has a very significant "downside" in that exposure to its dust can cause three fatal diseases: asbestosis, lung cancer, and mesothelioma of the pleura and peritoneum.

It has long been known that asbestos dust constitutes a danger to health; however, some issues, including the relative hazards of different types of asbestos and whether there is a safe level of exposure to any of them, remain in scientific dispute. ${ }^{12}$ Since the 1960s crocidolite has been regarded as a particular hazard, chiefly because of its strong association with mesothelioma. Amosite is widely regarded as scarcely less dangerous. In contrast, some have argued that pure chrysotile "may present little or no carcinogenic hazard" if uncontaminated by amphiboles. As recently as 2000, pure chrysotile was termed "a remarkably safe and valuable natural resource", which could be used to substantial public health advantage in the Third World. ${ }^{34}$ Others dismiss such views and demand an international ban on all forms of asbestos. ${ }^{5}$ Such scientific disputes and policy uncertainties conform to a long standing pattern whereby medical knowledge about the health hazards of asbestos dust has emerged slowly and sometimes falteringly since the early 20th century. As Irving $\mathrm{J}$ Selikoff, one of the foremost authorities on asbestos related disease in late 20th century America, once said, nature long held "some secrets ... rather close to its vest" ${ }^{\prime \prime}{ }^{6}$

\section{DISCOVERY OF A LINK BETWEEN ASBESTOS AND DISEASE}

The sequence of developing knowledge about asbestos and disease has generated historical controversy. ${ }^{7-13}$ Some even maintain that the health hazards of asbestos dust were appreciated in the ancient world; such claims have been convincingly refuted. ${ }^{14}$ Those doyens of occupational medicine, Thomas Arlidge and Thomas Oliver, ignored the hazards of asbestos in the late-Victorian and Edwardian periods (though Oliver addressed them subsequently). ${ }^{15}$ The first medical paper on the subject appeared in the British Medical Journal in $1924 .{ }^{17}$ Written by William Cooke of Wigan Infirmary's department of pathology, it briefly dealt with the illness and death from fibrosis of the lungs and tuberculosis of Nellie Kershaw, who had worked in the spinning room of a Rochdale asbestos factory. Following this case report, other papers soon appeared. These included articles by Oliver, who coined the word "asbestosis", though most observers have mistakenly attributed the term
Accepted 11 October 2003
Correspondence to:
Dr Peter W J Bartrip, Centre for Socio-Legal Studies, Wolfson College Linton Road, Oxford OX2 6UD, UK; peter. bartrip@csls.ox.ac.uk and fireproofing), warships (also for insulation and fireproofing), domestic products (such as ironing boards), and electrical distribution systems. The product ranges of the largest asbestos 


\begin{tabular}{|lc|}
\hline $\begin{array}{l}\text { Table 1 } \\
\text { USA, 1917-77 (10 year intervals) }\end{array}$ \\
\hline Year & Consumption (short tons) \\
\hline 1917 & 135338 \\
1927 & 226365 \\
1937 & 316263 \\
1947 & 616194 \\
1957 & 723492 \\
1967 & 720583 \\
1977 & 671543 \\
\hline US Department of Commerce. Bureau of Mines Mineral \\
Yearbook. Consumption peaked at 882 908 tons in 1973. \\
The vast bulk of American consumption (some 96\% in 1956) \\
consisted of chrysotile (white asbestos). \\
\hline
\end{tabular}

to Cooke, who used it in a 1927 paper that further explored the Kershaw case. ${ }^{18}{ }^{19}$ In 1928, following the discovery of a case of pulmonary fibrosis affecting a Glasgow asbestos worker, Britain's factory inspectorate took up the issue. Edward Merewether, a medical inspector based in Glasgow, was instructed to ascertain "whether the occurrence of this disease in an asbestos worker was merely a coincidence, or evidence of a definite health risk in the [asbestos] industry". ${ }^{20}$

At 36 years of age, Merewether was comparatively young when he embarked upon this task. He was also a newcomer to the inspectorate, having taken up his appointment only in 1927. Merewether's initial survey was soon followed by a full scale investigation, which he completed in October 1929. He found that occupational exposure to asbestos dust, particularly for prolonged periods at high concentrations, constituted a "definite occupational risk among asbestos workers as a class". ${ }^{21}$ The fibrosis of the lungs that could result might lead to "complete disablement" and death. ${ }^{21}$ His report endorsed a view expressed a few months earlier that a "new" disease, pulmonary asbestosis, had been discovered. ${ }^{22}$

Merewether had confirmed the existence of a new fatal disease, but he also believed that this disease was preventable. Dust control, he anticipated, "will cause, firstly, a great increase in the length of time before workers develop a disabling fibrosis, and secondly, the almost total disappearance of the disease, as the measures for the suppression of dust are perfected". ${ }^{21}$ At this point, Merewether's colleague, the engineering inspector of factories, Charles Price, investigated and recommended practical measures to control dust.

Following negotiations between representatives of the asbestos industry, the Trades Union Congress (largely in the person of its eminent medical adviser, Dr Thomas Legge, the first ever medical inspector of factories), individual unions, the factory inspectorate, and senior Home Office officials, the government enacted the Asbestos Industry Regulations, 1931. Implemented in full in 1933, these required the suppression of dust in the dustiest, and hence, apparently, the hazardous, areas of asbestos factories. ${ }^{23}$ With these measures in place, and for decades to come, it was widely agreed that the 1931 regulations had solved the problem of asbestosis in British asbestos factories. Thus, in 1955, Richard Doll referred to the infrequency of asbestosis and attributed its rarity to the "great reduction in the amount of dust in asbestos works" since the early 1930s. ${ }^{24}$ In the same year, Donald Hunter, then one of the leading authorities on occupational health, observed that the legislation had been "effective in controlling the disease" of asbestosis. ${ }^{25}$ Other distinguished figures, including Georgiana Bonser of Leeds University and Andrew Meiklejohn of Glasgow University, expressed similar views. $^{26} 27$
All of these opinions referred to the British experience; for years Britain's efforts to prevent asbestos related disease were not replicated elsewhere. In the USA, asbestos was mined, manufactured, and used in large quantities (table 1), but, apart from the patchy industrial hygiene measures established by some states beginning in the 1930s, little regulation pre-dated the federal Occupational Safety and Health Act of 1970. By this time scientific and regulatory attitudes towards asbestos disease had been transformed in several ways. Most significantly, it had been ascertained that asbestosis was not the only disease associated with exposure to asbestos dust.

\section{LINK WITH LUNG CANCER}

Suspicion that asbestosis might be linked with lung cancer began to emerge in the 1930s. ${ }^{28}{ }^{29}$ This link became more persuasive in the 1940s, even though doubts remained..$^{30-34}$ Then, in 1955, Doll established to the satisfaction of most informed observers that a causal association existed between asbestosis and lung cancer. ${ }^{24}$ He believed, however, that the Asbestos Industry Regulations had greatly reduced the risk of lung cancer for those who worked in Britain's asbestos factories. As he wrote in 1960, "It seems likely that the risk may now be largely eliminated". ${ }^{35}$

At this time, notwithstanding the discovery of a second asbestos related disease, there was every reason to suppose that the asbestos industry could continue to produce the fireproofing, insulation, and friction materials widely regarded as indispensable to modern life, provided that workers were protected from the heavy and prolonged exposures associated with asbestosis and lung cancer. In 1956, Meiklejohn dismissed the notion of a ban as "completely futile and absurd". ${ }^{27}$ Such views remained prevalent during the 1970s and even the 1980s. Irving Selikoff, along with the editorial pages of the Lancet, BMJ, and JAMA and other commentators, emphasised precautions over proscription of the mineral. ${ }^{36-39}$

The 1960s saw several important developments in the story of asbestos and disease. First, a third asbestos related disease, mesothelioma, was discovered. Second, it was shown that the hazards of asbestos dust were not confined to heavily exposed workers in asbestos factories but extended to insulation workers, other users of products containing asbestos, and people who lived close to asbestos factories..$^{4-44}$ There were even suggestions that urban dwellers, even in towns and cities remote from asbestos mines or factories, might face a hazard simply because they lived among buildings and cars containing asbestos. ${ }^{45}$ Third, even in Britain, with its well established and relatively high degree of regulation, some evidence suggested that asbestos related disease had ceased to decline and was possibly increasing. ${ }^{12}$ Fourth, in Britain and America at least, asbestos hazards began to attract increased media attention. Between 1964 and 1967, stories about the health hazards of asbestos appeared in such national newspapers as The Times, Sunday Times, Daily Herald, Guardian, Daily Telegraph, Morning Star, New York Times, and Wall Street Journal, as well as in local and regional papers. In January 1967, the BBC broadcast a film on the subject in its early evening news programme 24 Hours. Thereafter, asbestos health hazards regularly featured in newspaper and television reports. Fifth, in 1969, the first third party products liability suit claiming personal injury from asbestos was launched in the USA, thereby initiating the process that led to the demise of many large, well established, and successful companies.

\section{LINK WITH MESOTHELIOMA}

Cases of pleural mesothelioma were apparently detected in the nineteenth century, but the term itself had not appeared, and its occurrence was "so rare that some pathologists 
doubted its existence" ${ }^{\prime 4}{ }^{46}$ However, during the 1950s, South African researchers J C Wagner, Christopher Sleggs, and Paul Marchand began to identify cases of mesothelioma in the crocidolite mining district of Griqualand West. Curiously, they found no such cases in the vicinity of the Transvaal asbestos mines, even though the asbestos there was the same as in Griqualand West. This discrepancy initially suggested that the mesotheliomas in the Griqualand West district could have had an origin unrelated to asbestos exposure. Wagner, Sleggs, and Marchand first presented their findings at a conference in Johannesburg in 1959. Papers they published between 1960 and 1962 established a "possible association between the development of mesotheliomas of the pleura and exposure to asbestos dust in people living in the Cape asbestos fields". ${ }^{47-53}$ As this quotation indicates, the researchers had not established a clear causal association between exposure to crocidolite dust (let alone other forms of asbestos dust) and cases of mesothelioma among people who had never visited the northwest Cape. There was not long to wait. Papers published in 1964 and 1965 resulted in the general medical recognition of mesothelioma as an asbestos related disease. ${ }^{40-44}{ }^{54-60}$ Scepticism remained in some quarters, but, as a leading article in the BMJ later put it, by "the end of 1965 it was clear that asbestos workers are at special risk of developing ... mesothelioma". ${ }^{61}{ }^{62}$

Though other causal agents have been identified, for years asbestos dust (at least certain types of it) has been widely considered to be the principal or even the only cause of mesothelioma. ${ }^{63}$ Recently, however, the longstanding assumption that mesothelioma is solely caused by asbestos exposure has been called into question by the recognition that there are "many cases $(>20 \%)$ of mesothelioma for which there is little or no known exposure to asbestos" ${ }^{\prime 64} \mathrm{~A}$ causal association between asbestos and mesothelioma is not in dispute, but it has been widely proposed that the disease may also be causally linked with poliomyelitis vaccine contaminated with simian virus 40 (SV40), which was administered to millions of people in Europe and the USA between 1955 and 1963. Mayall et al have suggested a "synergistic interaction between asbestos and SV40 in human mesotheliomas". ${ }^{65}$ However, much remains in doubt. Carbone et al have warned against premature "conclusions about the possible role of SV40 in mesothelioma development in the general population". ${ }^{66}$ Likewise, Jasani et al have observed that the "causal link between SV40 and mesothelioma ... still needs to be examined further". ${ }^{67}$ More recently, Gazdar et al have pointed to "considerable evidence that SV40 has a causative role in the pathogenesis of mesothelioma", but caution that "the evidence is still insufficient to distinguish between association and causation". ${ }^{68}$ At present, therefore, it remains unclear whether a causal association exists between SV40 and elevated rates of mesothelioma. ${ }^{64-69}$

\section{EXTENT OF THE RISKS POSED BY ASBESTOS}

Recognition that asbestos related disease was not confined to unprotected workers in the dustiest locations dates from the 1960s and had much to do with the discovery of mesothelioma and the appreciation that relatively brief and light dust exposure could cause the disease years before its manifestation. A few isolated cases of asbestosis in insulation workers were reported in medical journals as early as the $1930 \mathrm{~s}^{70-72}$ Furthermore, as we now know, the US Navy and Maritime Commission appreciated the need to protect heavily exposed shipyard insulation workers in the early 1940s. ${ }^{73}$ This knowledge was not disseminated to a wider audience, however, and Asbestos Worker, the magazine of the US insulation workers' union, accurately noted in 1966 that "probably more attention has been focused on these particular health hazards in the last 3 or 4 years, than in the previous 30 or 40 years". ${ }^{74}$ The key figure in identifying the dangers of insulation work involving materials containing asbestos and exposure to even intermittent and light dust concentrations was Irving J Selikoff of Mount Sinai Hospital in New York City. Beginning in the early 1960s, with financial support from sources as diverse as the insulation workers' union and (from 1968) the Johns-Manville Corporation, Selikoff and his colleagues produced a stream of publications indicating, among other things, that insulators who worked with asbestos material in the USA faced an "important risk" of contracting asbestosis, lung cancer or mesothelioma, and possibly also gastrointestinal cancer. ${ }^{40-42} 7576$

In Britain the emergence of knowledge about mesothelioma and the hazards of insulation work coincided with the first doubts about the 1931 regulations. As a result, the factory inspectorate began revising these regulations in 1964. Five years later, following extensive consultation with business, scientists, and trades unionists, the Asbestos Regulations, 1969 were established. These allowed the continued use of asbestos only if maximum allowable concentrations of dust were not exceeded and if other precautions were observed. The regulations applied to all work sites and not, as previously, to asbestos factories alone. The maximum allowable concentration for crocidolite was set so low that its use was virtually eliminated. In the 1970s, 1980s, and 1990s further restrictions, both voluntary and statutory, were placed on the importation and use of asbestos. At their peak, in 1973, UK asbestos imports stood at some 190000 tonnes per annum; by 1997, the amount had fallen to 4820 tonnes of chrysotile, by then the only form allowed. ${ }^{12}$ Then, in July 1999, with one minor exception, the European Commission announced a European Union ban on all remaining chrysotile use by 1 January 2005. Britain implemented the ban some five years ahead of schedule in October 1999. Other European Union members have also beaten the deadline, and other countries have introduced their own bans. ${ }^{77}$ Elsewhere, including many parts of Africa, Asia, and South America, asbestos use remains widespread.

In the early 1970s, the US Occupational Safety and Health Administration (OHSA) identified asbestos as one of its first regulatory targets and introduced a range of controls. The OSHA reduced permitted exposure limits from $5 \mathrm{ff} / \mathrm{ml}$ (time weighted average) in 1972 to $2 \mathrm{ff} / \mathrm{ml}$ (time weighted average) in $1976 .^{78-80}$ As in Britain, stricter measures on the manufacture, importation, and processing of asbestos and products

\section{A chronology of medical discovery}

- 1924: W E Cooke publishes the first paper on asbestos related disease.

- 1925: Thomas Oliver coins the term "asbestosis".

- 1930: Edward Merewether confirms that inhalation of asbestos dust can cause a fatal disease.

- 1935: Kenneth Lynch and W Atmar Smith identify a "possible relationship" between pulmonary asbestosis and carcinoma of the lung.

- 1955: Richard Doll finds that certain asbestos workers face a "notably higher risk" of contracting lung cancer than the rest of the population.

- 1960: Wagner, Sleggs, and Marchand publish their first paper indicating a relationship between pleural mesothelioma and asbestos exposure.

- 1964: Selikoff, Churg, and Hammond demonstrate that insulation contract workers face a health hazard resulting from asbestos exposure. 


\section{Key references}

- Cooke WE. Fibrosis of the lungs due to the inhalation of asbestos dust. BMJ 1924;ii: 147.

- Merewether ERA, Price CW. Report on effects of asbestos dust on the lungs and dust suppression in the asbestos industry. London: HMSO, 1930.

- Doll R. Mortality from lung cancer in asbestos workers. Br J Ind Med 1955;12:81-6.

- Wagner JC, Sleggs CA, Marchand P. Diffuse pleural mesothelioma and asbestos exposure in the North Western Cape province. Br J Ind Med 1960;17:26071.

- Selikoff IJ, Hammond EC, Churg J. Asbestos exposure and neoplasia. JAMA 1964;188:22-6.

containing asbestos followed in the 1980s and 1990s. A permitted exposure limit of $0.1 \mathrm{ff} / \mathrm{ml}$ (fibres per millilitre) was introduced in $1994 .{ }^{81}$ Many of the companies that mined, manufactured, and used asbestos have gone out of business since the early 1980s under the burden of litigation. At present, asbestos use is heavily regulated and banned in most circumstances in the USA. A "comprehensive ban on asbestos in America" is envisaged. However, since exceptions are apparently anticipated if no alternative materials are available and it can be demonstrated that no damage to health or the environment will ensue, it remains to be seen how "comprehensive" this "ban" will be. ${ }^{82}$

\section{FUTURE OF ASBESTOS RELATED DISEASE}

Even if a worldwide ban on asbestos were to be introduced forthwith, past exposures will ensure that death and disease related to asbestos continue for the foreseeable future. Epidemiologists have predicted that the incidence of male mesothelioma in the USA should peak at about 2300 cases per year at the end of the 20th century and will decline to some 500 cases per year by about $2055 .{ }^{83}$ In 1995 , Julian Peto et al predicted that male deaths from mesothelioma in Britain will peak at between 2700 and 3300 per year around the year $2020 .^{84} \mathrm{~A}$ few years later, Peto et al forecast some 250000 male deaths from mesothelioma in Western Europe as a whole by about 2035. Most of these deaths are expected to occur among roofers, plumbers, electricians, carpenters, gas fitters, and others employed in the building trades. ${ }^{85}$ Others anticipate figures as high as 10000 per year among British males alone by $2020 .^{86}{ }^{87}$ It appears that the history of asbestos related disease still has some distance to travel.

\section{REFERENCES}

1 Stayner LT, Dankovic DA, Lemen RA. Occupational exposure to chrysotile asbestos and cancer risk: a review of the amphibole hypothesis. Am J Public Health 1996;86:179-86.

2 Yano $E$, Wang ZM, Wang XR, et al. Cancer mortality among workers exposed to amphibole-free chrysotile asbestos. Am J Epidemiol 2001;154:538-43.

3 Dunnigan J. Linking chrysotile asbestos with mesothelioma. Am J Ind Med 1988;14:205-9.

4 McDonald J. RE: Call for an international ban on asbestos. Why not ban asbestos? Am J Ind Med 2000;37:235.

5 Maltoni C. RE: Call for an international ban on asbestos. Am J Ind Med 2000;37:230-1.

6 Manville Trust Archive, Denver, Colorado. S986. Speech to the Construction Safety Association by Irving J Selikoff. Asbestos Disease in the Construction Industry 15 Nov 1976:2.

7 Wikeley N. The Asbestos Regulations 1931: a licence to kill? J Law Soc 1992;19:252-75.

8 Jeremy D. Corporate responses to the emergent recognition of a health hazard in the UK asbestos industry: the case of Turner \& Newall, 1920-1960. Bus Econ Hist 1995;24:254-65.
9 Greenberg M. Knowledge of the health hazard of asbestos prior to the Merewether and Price report of 1930. Social Hist Med 7:493-516.

10 Castleman BI. Asbestos: medical and legal aspects. 4th Ed. Englewood Cliffs: Aspen Law \& Business, 1996.

11 Tweedale G. Magic mineral to killer dust: Turner \& Newall and the asbestos hazard. Oxford: Oxford University Press, 2000.

12 Bartrip PWJ. The way from dusty death. Turner \& Newall and the regulation of occupational health in the British asbestos industry, 1890s-1970s. London and New York: Athlone Press, 2001.

13 McCulloch J. Asbestos blues. Labour, capital, physicians and the state in South Africa. Oxford: James Currey, 2002.

14 Browne K, Murray R. Asbestos and the Romans. Lancet 1990;336:445.

15 Arlidge T. The hygiene, diseases and mortality of occupations. London: Percival, 1892.

16 Oliver T, ed. Diseases of occupation from the legislative, social and medical points of view. London: Methuen, 1908.

17 Cooke WE. Fibrosis of the lungs due to the inhalation of asbestos dust. BMJ 1924;2:147.

18 Oliver T. Some dusty occupations and their effects upon the lungs. J Roy Sanitary Inst 1925-6;46:224-30.

19 Cooke WE. Pulmonary asbestosis. BMJ 1927;ii: 1024-5.

20 Chief Inspector of Factories and Workshops. Parliamentary Papers 192930;13 (Cmd 3360): Annual Report of the Chief Inspector of Factories and Workshops for 1928:559.

21 Merewether ERA, Price CW. Report on effects of asbestos dust on the lungs and dust suppression in the asbestos industry. London: HMSO, 1930.

22 Gloyne SR. The presence of the asbestos fiber in the lesions of asbestos workers. Tubercle 1929;10:404.

23 Statutory Instruments, 1931 No 1140.

24 Doll R. Mortality from lung cancer in asbestos workers. Br J Ind Med 1955;12:81-6.

25 Hunter D. The diseases of occupations. London: English Universities Press Ltd, 1955:881.

26 Bonser GM, Faulds JS, Stewart MJ. Occupational cancer of the urinary bladder in dyestuffs operatives and of the lung in asbestos textile workers and iron-ore miners. Am J Clin Pathol 1955;25:126-34.

27 Meiklejohn A. Silicosis and other fibrotic pneumoconioses. In: Merewether A ed. Industrial medicine and hygiene. London: Butterworth, 1956;3:116-17.

28 Lynch KM, Smith WA. Pulmonary asbestosis III: carcinoma of lung in asbestosilicosis. Am J Cancer 1935;24:56-64.

29 Chief Inspector of Factories. Parliamentary Papers 1938-9;11 (Cmd 6081): Annual Report of the Chief Inspector of Factories for 1938:1 18-19.

30 Gloyne SR. Abstracts. Bull Hyg 1944;19:362.

31 Homburger $\mathbf{F}$. The co-incidence of primary carcinoma of the lungs and pulmonary asbestosis. Am J Pathol 1943;19:797-807.

32 Cureton RJR. Squamous cell carcinoma occurring in asbestosis of the lung Br J Cancer 1948;2:249-53.

33 Wyers H. Asbestosis. Postgrad Med J 1949;15:631-8

34 Chief Inspector of Factories. Parliamentary Papers 1948-9;16 (Cmd 7621): Annual Report of the Chief Inspector of Factories for 1947:83-5.

35 Doll R. Occupational lung cancer. In: King EJ, Fletcher CM, eds. Industrial pulmonary diseases. London: J\&A Churchill, 1960:214.

36 Anonymous. Asbestos fiber ban not needed. Duluth Herald 31 March 1976

37 Anonymous. Asbestos in the air. Lancet 1976;i:944-5.

38 Anonymous. Exposure to asbestos dust. BMJ 1976;i:1361-2

39 Barclay W. Asbestos. An industrial asset with a health cost. JAMA 1984;252:96.

40 Selikoff IJ, Hammond EC, Churg J. Asbestos exposure and neoplasia. JAMA 1964;188:22-6.

41 Selikoff IJ, Hammond EC, Churg J. Relation between exposure to asbestos and mesothelioma N Engl J Med 1965;272:560-5.

42 Selikoff IJ, Hammond EC, Churg J. The occurrence of asbestosis among insulation workers in the United States. Ann N Y Acad Sci 196566;132:139-55.

43 Newhouse ML, Thompson H. Mesothelioma of pleura and peritoneum following exposure to asbestos in the London area. $\mathrm{Br} J$ Ind Med 1965;22:261-69.

44 Newhouse ML, Thompson H. Epidemiology of mesothelial tumors in the London area. Ann N Y Acad Sci 1965-66; 132:579-88.

45 Thomson JG. Asbestos and the urban dweller. Ann N Y Acad Sci 196566;132:196-214.

46 Doig AT. Asbestos disease. Health Bull 1968;26:24-29.

47 Wagner JC, Sleggs CA, Marchand P. Diffuse pleural mesothelioma and asbestos exposure in the North Western Cape province. Br J Ind Med 1960;17:260-71.

48 Sleggs CA. Clinical aspects of asbestosis in the northern Cape. In: Orenstein A ed. Proceedings of the Pneumoconiosis Conference held at the University of Witswatersrand, Johannesburg, 9-24 February, 1959. London: Churchill, 1960:383-90.

49 Wagner J. Some pathological aspects of asbestosis in the Union of South Africa. In: Orenstein A, ed. Proceedings of the Pneumoconiosis Conference held at the University of Witswatersrand, Johannesburg, 9-24 February, 1959. London: Churchill, 1960:373-82.

50 Sleggs CA, Marchand P, Wagner JC. Diffuse pleural mesotheliomas in South Africa. S Afr Med J 1961;35:28-34.

51 Wagner J. Experimental production of mesothelial tumours of the pleura by implantation of dusts in laboratory animals. Nature 1962;1961:80-1.

52 Marchand P. The discovery of mesothelioma in the Northwestern Cape province in the Republic of South Africa. Am J Ind Med 199;192:41-6.

53 Wagner J. The discovery of the association between blue asbestos and mesotheliomas and the aftermath. Br J Ind Med 1991;48:399-403. 
54 Hourihane DO'B. The pathology of mesotheliomata and an analysis of their association with asbestos exposure. Thorax 1964;19:268-78.

55 Enticknap J, Smither W. Peritoneal tumours in asbestosis. Br J Ind Med 1964;21:20-31.

56 Owen WG. Diffuse mesothelioma and exposure to asbestos dust in the Merseyside area. BMJ 1964;ii:214-18.

57 Elmes PC, McCaughey WTE, Wade OL. Diffuse mesothelioma of the pleura and asbestos. BMJ 1965;i:350-3.

58 Owen WG. Mesothelial tumors and exposure to asbestos dust. Ann N Y Acad Sci 1965-66;132:674-79.

59 Wagner JC. Epidemiology of diffuse mesothelial tumors: evidence of an association from studies in South Africa and the United Kingdom. Ann N Y Acad Sci 1965-66;132:575-88.

60 Elmes PC, Wade OL. Relationship between exposure to asbestos and pleural malignancy in Belfast. Ann N Y Acad Sci 1965-66;132:549-57

61 Willis RA. Pathology of tumours. London: Butterworths, 1967:181-2.

62 Anonymous. Cancer and asbestos. BMJ 1968;iii:448-9.

63 Peterson JT, Greenberg SD, Buffler PA. Non-asbestos-related malignant mesothelioma: a review. Cancer 1984;54:951-60.

$64 \mathrm{McConnell} \mathrm{EE,} \mathrm{Carbone} \mathrm{M.} \mathrm{A} \mathrm{comparison} \mathrm{of} \mathrm{pleural} \mathrm{mesotheliomas} \mathrm{induced}$ by asbestos or SV40 virus in Syrian golden hamsters. Inhalation Toxicology 2000;12(suppl 3):173-81.

65 Mayall FG, Jacobson G, Wilkins R. Mutations of P53 gene and SV40 sequences in asbestos associated and non-asbestos-associated mesotheliomas. J Clin Pathol 1999;52:291-3.

66 Carbone M, Fisher S, Powers A, et al. New molecular and epidemiological issues in mesothelioma: role of SV40. J Cell Physiol 1999;180:167-72.

67 Jasani B Jones CJ, Radu C, et al. Simian virus 40 detection in human mesothelioma: reliability and significance of the available molecular evidence. Frontiers in Bioscience 2001;6:e12-22.

68 Gazdar AF, Butel JS, Carbone M. SV40 and human tumours: myth, association or causality. Nat Rev Cancer 2002;2:957-64.
69 Roggli VL. Mineral fiber content of lung tissue in patients with malignant mesothelioma. In: Henderson DW, Shilkin KB, Langlois SLP, Whitaker D, eds. Malignant mesothelioma. New York: Hemisphere, 1992:201-22.

70 Ellman P. Pulmonary asbestosis: its clinical, radiological, and pathological features, and associated risk of tuberculosis infection. J Ind Hyg 1933;15:181.

71 Ellman P. Pulmonary asbestosis. Br J Radiol 1934;7 new series:289-90.

72 Wood W, Gloyne SR. Pulmonary asbestosis. A review of one hundred cases. Lancet 1934;ii: 1383-5.

73 Corn JK. Response to occupational health hazards. A historical perspective. New York: Van Nostrand Reinhold, 1992:89-107.

74 Anonymous. Asbestos Worker 1966;16:16.

75 Selikoff IJ, Hammond EC, Churg J. Asbestos exposure, smoking and neoplasia. JAMA 1968;204:106-12.

76 Selikoff IJ, Lee D. Asbestos and disease. New York, San Francisco and London: Academic Press, 1978.

77 LaDou J, Landrigan P, Bailar JC III, et al. A call for an international ban on asbestos. Can Med Assoc J 2001;164:489-90.

78 Anonymous. Federal Register 1972;37:11318-22.

79 Anonymous. Federal Register 1975;40:47, 652, 657

80 Mintz B. OSHA. History law and policy. Washington: BNA Books, 1984.

81 Corn JK. Environmental public health policy for asbestos in schools. Boca Raton: Lewis Publishers, 1999:12.

82 Dayton: Senate takes major step toward banning asbestos (www.senate.gov) 〜dayton/releases/2003/06/2003625944.html).

83 Price B. Analysis of current trends in United States mesothelioma incidence. Am J Epidemiol 1997; 145:211-18.

84 Peto J, Hodgson JT, Matthews FE, et al. Continuing increase in mesothelioma mortality in Britain. Lancet 1995;345:535-9.

85 Peto J, Decarli A, La Vecchia C, et al. The European mesothelioma epidemic. $\mathrm{Br} J$ Cancer 1999;79:666-72.

86 De Vos IH. Mesothelioma. Lancet 1995;345:1233.

87 Webb J. Tragic asbestos error will kill thousands. New Scientist 1995; 145:4. 